\title{
REFORMING THE THAI PRINT MEDIA $^{1}$
}

\section{Duncan McCargo ${ }^{2}$}

\section{Introduction}

The Thai language press performs an important political role. At salient junctures, such as the May 1992 protests against the Suchinda government, or the May 1995 no-confidence debate which brought down the Chuan government, the media can play an important role in informing the public about political developments, or in tipping the balance of popular opinion. On occasion (as in May 1992), this role may correspond closely with that of an advocate of the public interest. At other times (as in May 1995), it may more reflect the partisan interests of elements of the press themselves. Hence the media is an essentially unreliable and fickle political actor. An unpredictable 'trickster'. The unreliability of the Thai press is deeply rooted in its history, organisational culture, newsgathering system, and working practices. It reflects the origins of newspapers in Thailand; the press has long functioned as a political space in which different elite groups have sought to advance their interests and views. The restrictions on open expression which existed during the period of absolute monarchy were continued during

${ }^{1}$ Paper presented to the panel on 'The Media, Cultural Politics and the Nation- State', at the $7^{\text {th }}$ International Conference on Thai Studies, Amsterdam, 4-8 July 1999.

2 Dr. Duncan McCargo, Institute of Politics and International Studies, University of Leeds, Leeds LS 2 9JT, UK. Phone+44 113233 6865, fax 233 4400, e-mail d.j.mccargo@,leeds.ac.uk later periods of authoritarian and military rule, especially during the Cold War. The press was not concerned with presenting factual accounts of events; still less it interested in offering systematic explanations and analyses of developments. On the contrary, the press was often dedicated to obfuscation, mystification, and the sowing of confusion. The core material of the press was neither facts nor analysis, but opinion. The existence of a politically powerful monarchy which was effectively off- limits for open discussion in the media served to reinforce the culture of rumour, and undermined any serious analysis of the Thai order. This does not mean, however, that the press was supine and uncritical. Far from it, Thai newspapers often were aggressive and outspoken, hiding their lack of substantive critical bite behind a noisy façade of vociferous bark.

By the 1970s, newspapers were content to follow, rather than to lead, public opinion; according to Boonrak:

The decay of political morality resulted in unimaginative journalism which tamely conformed to the political whims of the military men in power. Businessmen who invested in newspaper enterprises in this political setting seemed to seek merely commercial ends from newspaper publishing... Thai Rath, the pro - Sarit newspaper founded in 1958 , served as an ideal model since it had been the giant of the 
popular press in terms of
circulation.

Many writers have portrayed 1992 as the Thai print media' $\mathrm{s}$ finest hour. ${ }^{4}$ Faced with a government which controlled parliament, the military, the bureaucracy, and the electronic media, the press joined forces with opposition parties and protest groups to bring down Suchinda. The crowds of protestors in Bangkok were not simply opposed to Suchinda Kraprayoon's becoming premier, they were objecting to a political order in which the military and the bureaucracy exerted tremendous influence.

This image of the Thai press as the courageous guardian of liberty and democracy contains a great deal of truth. At the same time, a complete understanding of the role of the press in the May events requires a more nuanced analysis. Ubonrat notes that:

For the first time in history, the majority of the press united against state suppression of freedom of expression. Professionalism and press

${ }^{3}$ Boonrak Boonyaketmala, 'Thailand', in John A. Lent (ed.), Newspaper in Asia: contemporary trends and problem, Hong Kong: Heinemann Asia, 1982, p. 344.

${ }^{4}$ For arguments along these lines, see Thitinan Pongsudhirak, 'Thailand's media: whose watchdog?', in Kevin Hewson (ed.), Political change in Thailand: democracy and participation, london: Routledge 1997, pp.224-5; Dancan McCargo, 'The buds of May', index on Censorship, April 1993, pp. 3-8; and Ubonrat Siriyuvasak, "The development of a participatory democracy: raison d'être for media reform in Thailand', Southeast Asian Journal of Social Science, 22, 1994, pp. 101-5. autonomy prevailed over any
political patronage 5

The key word here is 'majority'; some elements of the press were not wholeheartedly behind the anti - Suchinda campaign, and others were downright sympathetic towards Suchinda. Political patronage may not have prevailed in the May crisis, but it was still an important issue. The anti - Suchinda role of the Reporters' Association of Thailand during the May events represented the stance of one particular group. ${ }^{6}$ Certain newspapers, notably The Nation, Phujatkan and Naew $\mathrm{Na}$, took the lead in resisting Suchinda. Phujatkan was closely allied with the political enemies of the NPKC, whilst Naew Na enjoyed strong personal ties with the opposition New Aspiration and Palang Dharma parties. The stance of other major newspapers was much more ambivalent. Matichon had close links with the NPKC, and its owner was a personal friend of Suchinda's. Although Matichon staff insisted that they were on the 'right' side in May 1992, the public perception of the newspaper was that it could not be trusted in this particular crisis. ${ }^{7}$ Similarly with the top-selling newspaper Thai Rath. A master's thesis by a Chulalongkorn University student demonstrated that Thai Rath was broadly supportive of the

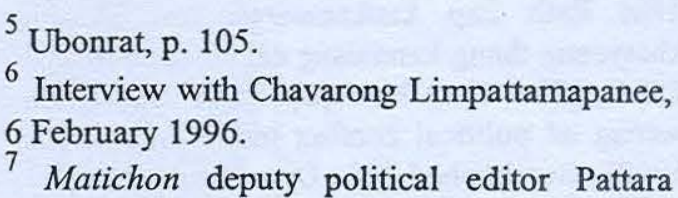
Khumphitak expressed irritation at the praise of Phujatkan's actions in the May events (such as giving away special issues free), and pointed out that during the demonstrations Matichon removed out all advertising, ran a 16 page paper (which lost money) full of news, and reported all the events in full. Interview, 4 Auguat 1995. 
Suchinda premiership, only changing sides when the anti - Suchinda protests built up an irresistible momentum. ${ }^{8}$ In other words, the stance of the press during the May events was largely a function of the personal alliances of key columnists, editors and owners. The press was far from monolithic. Whilst the print media was infinitely more oppositional than the captive electronic media, the quality coverage in the press varied significantly from one publication to another.

A similar picture emerges from the events of May 1995. The Chuan government was ousted after an intensive campaign against it, led by Thai Rath in conjunction with opposition politicians. Pasuk and Baker note that the press became stronger more sophisticated as a result of its successful role in challenging the military during the May 1992 protests; they also declare baldly that: 'The Chuan government (1992-95) was brought down after a campaign by Thai rat to expose abuses of a land distribution scheme in Phuket'? Thitinan agrees that it was 'not the opposition's efforts, but unrelenting press inquisitions' which led to Chuan's downfall. ${ }^{10}$ These assertions raise important questions: how justified was Thai Rath in pursuing the land

8 Pajaree Tanasomboonkit, Nangsuephim Thai Rath kap kankamnotwarasan khwam khatyaeng thang kanmuang nai hetkan pritsapa 2535', [Thai Rath Newspaper and the agenda setting of political conflict in the May crisis 1992], unpublished MA. Dissertation, Faculty of Communication Arts, Chulalongkorn University, 1995.

${ }^{9}$ Pasuk Phongpaichit and Chris Baker, 'Power in transition: Thailand in the 1990s', in Kevin Hewison (ed.), Political change in Thailand: democracy and participation, London: Routledge 1997, pp. 33-5.

${ }^{10}$ Thitinan, p. 226. reform issue as it did, and how far could press coverage had been responsible for the demise of Chuan? Chatcharin Chaiyawttn strongly disagrees. ${ }^{11} \mathrm{He}$ argues that the demise of the Chuan government resulted from simple parliamentary arithmetic: once Palang Dharma pulled out, Chuan did not have enough seats and could not persuade any other party to join him. At the same time, the reasons for Palang Dharma's withdrawal and the reluctance of other parties to join Chuan were undoubtedly related to the popular mood of opposition to the Democrats generated partly by the press campaign. Technically, Chatcharin is right to argue that Chuan was defeated by the collapse of his coalition, but the press (led by Thai Rath) undoubtedly assisted in bringing about that collapse. Given that the Chuan administration was replaced by a less progressive, more corrupt, less competent and generally far more distasteful government (the Banharn government of July 1995 to November 1996), ${ }^{12}$ the wisdom of the press in helping hound the Democrats from office may be questioned.

\section{Features of the Thai language Press}

What began as obstacles to a spirit of free journalistic inquiry (the monarchy, the Cold War, the threat of closure by an authoritarian regime) became institutionalised into the working practices of the Thai press. The political sections of newspapers are largely written by two types of practitioner: reporters, who collect the opinions of big shots in the political world, and columnists, who are themselves big shots, and sound off

\footnotetext{
${ }^{11}$ Interview with Chatcharin Chaiyawttn, 7 February 1996.

12 On relations between the media and Banharn government, see Gordon Fairclough, 'Free to air' Far Eastern Economic Review, 16 November 1995.
} 
opinions of their own. Analysis is the sole responsibility of columnists, who were already senior figures. But in practice, their 'analysis' is largely a matter of their personal opinion. What is largely absent is the sense of a duty on the part of newspapers to inform and explain political developments to readers who are not 'in the know', who needed concise and accessible information. Columnists often prefer to write in an opaque fashion, demonstrating their own inside knowledge; in this way they try to show their seniority and importance, their power over others. In the Thai language press there are very few journalists, people whose job it is to write balanced stories explaining and analyzing political developments. According to the Thai theory of news - writing, there is an absolute distinction between news and comment which effectively precludes the press from 'guiding' the reader about what is happening. The result of this half- baked theory is that the hapless Thai reader is left largely in the dark, forced to try and piece together clues from rambling, incoherent, front page political stories which consist of nothing other than quotations. Small wonder that Thai newspapers have such low sales. The Thai press also reflects the hierarchism which is such a pervasive feature of Thai society. Only phu yai (senior people) count; ordinary people are irrelevant, unmentioned, and voiceless. Political news is gathered at national level locations, especially Government House and Parliament; there is no proper coverage of political events outside Bangkok. Another feature of the Thai news media is its Bangkok focus. The extent to which Bangkok Thais are Bangkok- centric in their perception of Thailand is difficult to exaggerate; to the non - Thai, it can appear difficult to credit. The division of editorial departments into desks is revealing: typically, Thai newspapers have desks for types of news such as crime, politics, business, foreign news, ${ }^{13}$ sport, women, environment and entertainment. In addition to these, they have a separate desk for 'provincial' news. Any news story which breaks outside Bangkok is first and foremost a provincial story; only in a secondary sense will it be considered a crime story, a political story, or whatever.

Thai newspapers do not, as a general rule, ${ }^{14}$ maintain proper news bureaux staffed by career reporters in provincial areas. Instead, provincial news is the domain of stringers, who are paid largely by the story. Outside Bangkok is simply the provinces, where nothing of political significance is deemed to occur, unless the prime minister or some other phu yai deigns to make an upcountry visit. The weakness of the system of provincial stringers was clearly illustrated during the run-up to the May 1995 no-confidence debate, when the Chuan Leekpai government was under attack over its handling of a land reform programme. Controversial former deputy agriculture minister Suthep Theuksuban, the figure at the centre of the scandal, made a fiery and entirely unrepentant in his Southern constituency of Surat Thani on 18 April. He called upon his supporters to march on Bangkok in their hundreds of thousands, to back up his stance on land reform. Local stringers in the province filed reports on the rally for all the main Bangkok dailies, but

${ }^{13}$ On foreign news coverage in the Thai press, see Duncan McCargo, 1999 'The international media and the domestic political coverage of the Thai press', Modern Asian Studies. 33. 3: 551-579.

${ }^{14}$ The Nation and Phujatkan Daily have made efforts to establish regional bureaux in cities such as Chiang Mai and Khon Kaen, though these bureaux complement rather than replace traditional 'stringers'. 
took the precaution of omitting Suthep's rabble- rousing call for a march on Bangkok. The only newspaper to get the story was Siam Post, which had flown one of its Bangkok - based political reporters down to Surat to listen to Suthep's speech. Once the story had appeared all over the front page of Siam Post, it was quickly picked up by other national newspapers and became a major issue, further undermining the credibility of the Democrats. ${ }^{15}$ Yet the fact that an important development could be missed by all but one of the. National papers because of self - censorship on the part of their stringers illustrated the weakness of the stringer system, and begged the question: how many significant issues and developments (especially 'upcountry') were missed by the national press simply because of structural problems in their newsgathering operations? The overall effect of the garbled and incoherent political coveraged in the Thai press is simply to reinforce a deeply dysfunctional political system.

Matichon is typical of Thai newspapers in drawing sharp distinctions between different types of news: each type of news is covered by its own desk, and appears on a different page. The main desks in 1995 were: front page desk, political desk, economic desk, provincial news desk, agriculture and technology desk, crime desk, Bangkok news desk, education desk, health news desk, environment desk, labour desk, foreign news desk, sports desk, popular culture desk (music, movie and TV news), women's desk, and society desk. Reporters were assigned to specific desks, and were generally based at specific geographical locations, typically ministries or other government agencies. A problem common among Thai reporters was one of

${ }^{15}$ Siam Post, 19 April 1995. bureaucratisation: reporters who worked constantly alongside government officials, from a 'reporter's room' within a government department, using government provided telephones, fax machines, typewriters and other facilities, often tended to view the issues they covered from a perspective similar to that of bureaucrats, and had a tendency to become passive mouthpieces for the official line.

Deputy political desk chief Chamlong ${ }^{16}$ argued that a good proportion of Matichon reporters had views regarding important questions which reflected influence they had received from bureaucrats. This applied less to political desk than to economic desk reporters: 'Ministry-based reporters (nak khao prajam krasuang) is what we call them in Thailand, and they really are based at the ministry!' Based on his own experience as a reporter at the Communications Ministry, he argued that reporters spent much of their time waiting around for the arrival of senior officials.

This is the way they work: Has the permanent secretary arrived yet? Let's go and talk to him... Has the deputy director arrived yet? Let's go and talk to the deputy director... and so on. These sorts of people think very conservatively. The reporters start to think in the same way.

Ministry - based reporters rarely sought to check information given them by bureaucrats with sources in the private sector, a serious weakness in a complex and rapidly changing area such as communications policy. Senior editor and columnist Sathian Janthimathon also argued
16 Interview with Chamlong Dokpik,
8 August 1995 . 
that reporters were becoming more like bureaucrats, while Matichon itself was becoming increasingly conservative. ${ }^{17}$

A further problem wad the failure of many reporters to see the ways in which issues crossed over the arbitrary divides created by the organisation of news desks. In particular, political reporters consistently failed to understand the financial and economic implications of debates about policy and legislation, whilst economic reporters did not recognise that many economic developments were being driven by political imperatives. ${ }^{18}$ This was especially the case when ministries were controlled by moneyoriented provincial machine politicians, of the kind who dominated the 1995 Banharn 1 Cabinet.

Reporters at assignments such as Government House, the Finance Ministry, the Communications Ministry, or the Defence Ministry were constantly covering issues which straddled the divide between politics and economics, but for the most part they tended to reduce these issues either to politics or to economics, depending upon their own desk affiliation. Julalak, ${ }^{19}$ a front page editor with a background on the economics desk, admitted that economic reporters were often very ill-informed about politics sometimes phoning in to ask what was going on politically. They had to be urged to read political news so that they could discuss, since many news sources regarded Matichon as a political newspaper.

17 Interview with Sathian Janthimathon, 6 February 1996.

18 See Duncan McCargo and Ramaimas Bowra, Policy advocacy and the media in Thailand, Bangkok: Institute of Public Policy Studies, 1997.

19 Interview with Jalalak Poogrid, 7 August 1995.
The same applied to reporters from the health and education desks, who covered the relevant ministries from a narrow policy angle, often failing to spot the political significance of issues within their domains.

In defence of these reporters, it might be argued that they were essentially specialists in their own areas rather than generalists and that keeping them at the same location allowed them to build up contacts and increase their specialist expertise. Sathian argued that Matichon badly needed more specialist reporters; however, most of the existing reporters simply had a limited perspective rather than a specialist understanding. ${ }^{20}$ Chamlong (like Sathian) argued that in fact most ministry - based reporters were not 'specialists' in any useful sense: they lacked in-depth knowledge of the fields they covered, and lacked the capacity to understand how those fields inter-related with other areas. In other words, such reporters were actually 'narrowists', rather than genuine specialists. To a large degree, these weaknesses reflected failings of the Thai education system.

Although improved training is clearly desirable, in some cases it served mainly to increase reporters' frustration. One reporter from Phujatkan (not a parliamentary reporter) described how she had attended a one month journalism training course run by her company, but on completing it had found it impossible to implement many of the new ideas she had learned. ${ }^{21}$ It is all too easy to scapegoat inexperienced reporters and argue that they needed more training; the core problems with political newsgathering were structural ones. Until

20 Interview with Sathian Janthimathon, 6 February 1996.

${ }^{21}$ Interview, 20 October 1995. 
political news is defined more broadly than simply a recitation of quotations, there was little point in training Thai political reporters to international standards. Thai political reporters in locations such as parliament are simply the front line casualties of inept interactions between a defective media and a deficient political order.

\section{The Pravien murder: falling between desks}

On 11 July 1995, just as the Banharn coalition was preparing to announce its ministerial lineup, a political murder took place in the Northeastern province of Loei. The victim, Khru Pravien Bunnak, was a leader of the local branch of the Assembly for Small-scale Northeastern Farmers (ASNF). The ASNF was a leading people's organisation, a network of political and social activists which campaigned on a wide range of causes across the region. In the past, the ASNF had often come into conflict with the government, and with powerful provincial politicians. Pravien had been leading a campaign against quarrying in the province. Tossapol had a stake in the Surat Quarry Company, against whose operations Pravien had orchestrated a protest. ${ }^{22} \mathrm{He}$ was shot dead in broad daylight in front of a crowd of witnesses.

The timing and circumstances of Pravien's death clearly pointed to a political crime, closely related to conflicts had come to a head during the recent election campaign. Pravien had been a strong but unsuccessful candidate in the campaign, coming in forth in Loei's District 2 with 38, 129 votes. His candidacy had helped dislodge incumbent Chart Thai MP Tossapol Sungkhasup from his seat. At the same time, the event itself

22 The Nation, 13 July 1995. was a police matter. The campaign against quarrying was actually an environment issue, involving questions of provincial business, but organised by a group of farmers. Was this a matter for the political desk, the crime desk, the environment desk, the economic desk, the agricultural desk, or what? An event such as the Pravien killing, which took place at the intersection of several different desk domains, posed a serious challenge for a newspaper such as Matichon. A messy and complex story, it went to the heart of the illicit influence and violence which characterised provincial politics. Pravien's exposed the seamy side of the recent election, the utter corruption of politicians in the government coalition. Handling a story like this would push Matichon's news resources to their limits. Although the newspaper had its own stringer in Loei, everyone knew that a story of this kind could not be successfully covered by a local person. Any stringer would be too the situation to report on it effectively. Local people were under great pressure to cover up the real circumstances which led to the crime. As one local activist told The Nation:

I believe most of the local authority officials are so scared of the dark influences in this province that nobody tries to do what is right. ${ }^{23}$

Only a reporter (preferably a team of reporters) sent from Bangkok would stand any chance of getting to the heart of the issue. Factual news reports about who said what, where and when (the kind of news normally sent in by provincial stringers) would not be sufficient: this was a story which needed detailed investigation. Here was a moment when Matichon needed to

23 Nirirat Subsomboon, co-ordinator of the People's Friends group, quoted in The Nation, 30 July 1995. 
despatch its top reporters to Loei, on the first available flight. An instant decision was needed. Yet no such decision was taken. The event had taken place in the provinces: it was therefore a matter for the provincial desk to deal with. Other people did not want to tread on the toes of the provincial desk. The local stringer was said to be able to handle the story. The story might only last a couple of days. It would be expensive to send reporters to Loei. No one, either at front page editor or managing editor level, seemed able to say 'This is a big story. We can't ignore of downplay it because it's a provincial story. We must pursue it.' The political desk would not consider pulling one of its reporters off politician-tagging duties to pursue a hot story upcountry. In any case, the political reporters would not know what to do in Loei. They operated within the narrow parameters of the Bangkok parliamentary and ministerial scene. Quite simply, Matichon had no top reporters who could be despatched anywhere. The only people who could easily have been freed up for the task were some of the 'floating' front page editors, none of whom would have been seen dead in Loei. Like other Thai newspapers, Matichon had stringers in hundreds of districts the length and breadth of Thailand. What Matichon actually needed, however, was not reporters in every town, but reporters who were capable of going to any town.

Other newspapers did respond to the challenge of the Pravien case more effectively: both Matichon's downmarket sister-paper Khao Sod, and the political daily Siam Post, despatched reporters from their political desks to Loei immediately. Both newspapers carried detailed news coverage of the case, as did Daily News.
While Siam Post ${ }^{24}$, plus Phujatkan ${ }^{25}$ and Krungthep Thurakit ${ }^{26}$ (both of which had Northeastern regional news bureaux in Khon Kaen) ran in-depth pieces on the story, Matichon did not run a single substantive analytical article on the Pravien case. The poor response of the paper in the coverage of the Pravien case testified to a serious paralysis in Matichon's editorial department. It is especially ironic that Matichon, with its declared aim of serving a national readership, ${ }^{27}$ was scooped on this provincial news story by newspapers such as Siam Post, whose sales outside Bangkok were negligible.

For a newspaper to adopt strong political stances which antagonised important powerholders is always risky. Politicians and other influential figures had numerous tactics at their disposal for toning down press criticism, ranging from co-optation. Any newspaper which sought to take on a powerful individual or group needed strong backing. ${ }^{28}$ As Girling noted, 'with powerful protectors behind them, newspapers may also denounce or libel adversaries to a remarkable degree'. ${ }^{29}$ For example, when

24 See Siam Post, 14 August 1995, and 19 August 1995.

${ }^{25}$ See Phujatkan Daily, 24 August 1995, and 28 August 1995.

${ }^{26}$ See Krungthep Thurakiy, 24 July 1995, and 2 August 1995.

${ }^{27}$ 'Recognising that the people in the provinces beyond Bangkok represent the national majority, three pages instead of the original one-are now being devoted to provincial news reports'. Matichon Public Co. Ltd., Annual Report. 1994, p. 31.

${ }^{28}$ Interview with Chatcharin Chaiyawttn, 27 March 1995.

29 John L.S. Girling, Thailand: society and politics, Ithaca: Cornell University Press 1981, p. 172. 
Chatichai Choonavan was ousted by the National Peace-keeping Council in the 1991 military coup, Ssondhi Limthongkul, the owner of the Phujatkan group, used his newspapers to attack and undermine the NPKC's credibility. He did so with the tacit backing of Chatichai, and with the active support of a group of people who had been close to the Chatichai government. When the NPKC was ousted from power after the bloody events of May 1992, Sondhi publicly called for Chatichai to be given a chance to return to the premiership, illustrating the extent to which he was allied with the exprime minister.

Similarly, Thai Rath, with formidable contacts in the political world, was well placed to challenge power-holders. Yet the preferred style of Thai Rath was to achieve a modus vivendi with the government of the day. It would typically do this by first criticising and attacking a new administration, until the administration granted it respect and privileges in terms of access to information (not to mention business privileges). Generally, successive prime ministers would conclude that it was in their interests to kowtow to Thai Rath. General Prem Tinsulanond (1980-88), for example, who was always anxious that the press should not scrutinise his private life, cultivated excellent relations with Thai Rath's owner Khamphol Wacharapon. It is no coincidence that Prem was able to serve a remarkable eight years in office. Newspapers such as Thai Rath, and to a lesser extent Matichon, were able to cooperate pragmatically with governments of different varieties. Both welcomed the February 1991 coup and befriended the NPKC, but both were ready to denounce the coup makers in May 1992 when they lost power.
A common focus of domestic criticism concerns allegations of corrupt practices by reporters and columnists. While there is ample evidence that some such practices exist, the fundamental weaknesses of the Thai press are structural ones, rather than matters of individual ethics. Blaming the shortcomings of the press on the supposed immorality of some newspaper staff diverts attention from the core issues of dysfunctional political coverage, in much the same way as news stories about corrupt politicians may distract attention from underlying problems in the political order.

The shortcomings of political coverage in the Thai press reflect organisational problems within Thai newspapers, problems such as: internal strife between different factions within editorial departments, weak systems of news meetings, poor coordination between desks, conflicts of interest involving the personal connections of owners, editors, and columnists, loss of editorial credibility because of such connections, tensions between desk chiefs and senior editors, lack of specialist knowledge by newspaper staff and consequent inability by the press to follow complex developments, especially those which crossed the traditional divide between business stories and political stories, and a poor system for covering provincial news. Such problems affect even well - established, top - selling newspapers, and are even more acute lower down the ladder.

Such shortcomings mean that even when presented with a politically explosive story backed by solid evidence, a Thai newspaper can easily seriously mishandle it. The 'Dr. S' story run by Siam Post in December 1995 clearly illustrated the limitations of Thai language newspapers in pursuing their own 
agendas. ${ }^{30}$ The news - gathering systems of Thai newspapers made it difficult for them to assign resources to investigative journalism. Even when they had an outstanding story, backed by impressive documentary evidence, newspapers could not count on being able to create the necessary krasae (current of opinion) to influence political events. In particular, there was no tradition of resignation by politicians, and the parliamentary committee system was ineffective. The use of libel actions by politicians gave them a powerful weapon with which to threaten newspapers, and once a libel action had been initiated a politician could evade reporters' questions about a sensitive issue on the grounds that the matter was judice. Well - connected public figures could lobby newspapers to have embarrassing stories dropped or toned down. Most importantly of all, newspapers failed to act cohesively over scandals and public interest stories; competition between newspapers, and resentment against smaller papers carrying scoops, helped questionable politicians remain in office. The 'Dr. S' story was an heroic failure, a story which might have led to the prompt ouster of a tainted minister, but instead contributed to the downfall of a crusading newspaper.

The desire of Thai newspapers to monopolise important stories is often counter-productive; instead of a struggle between the press and the political establishment, in which the press unites to expose wrongdoing, a struggle may emerge between rival newspapers, one trying to expose wrongdoing, and the rest trying to kill off the story. Thai newspapers lack the capacity for proper investigative reporting, relying instead upon information leaks from

30 For details, see McCargo, Media machinations, forthcoming. important sources. They are generally unable to substantiate such leaks with their own supplementary investigations or research. In presenting a complex story involving allegations of wrongdoing, Thai newspapers lack the mechanisms for explaining their allegations clearly: stories of this kind cannot be separated out into parcels of 'news' and 'comment', but require an integrated analysis and explanation which is inimical to Thai theories of press coverage. If a newspaper fails to generate sufficient momentum of interest in its story, the story may by destined to degenerate into a pile of aggressive headlines and seemingly random insinuations. The all - pervasive 'news' versus 'comment' distinction reduces political stories to their lowest common denominator, making serious analysis or the exposition of complex issues almost impossible. Investigative journalism can scarcely be said to exist in the Thai language press. This limitation restricts the political role of the press, which can harass and terrorise political figures.

The Thai press has become quite adept at bringing down governments (in league with other elements of Bangkok civil society), and played a leading role in ending successively the Suchinda (1992), Chuan (1995), Banharn (1996), and Chavalit (1997) administrations. When a prime minister needed to be kicked out, sections of the press were always on hand to put the boot in. The larger problem was with the political role of the press in peacetime, when no big crisis was at hand, and the newspapers had to do the more mundane job of analysing and explaining the government's performance, and articulating the views of different interest groups, including the marginalised and dispossessed. Always angling for a fight, the press is largely inept at the day-today business of scrutinising Thailand's politics. The comment - based newsgathering 
system, and the polemical character of most columnists, is designed to provoke slanging matches, rather than expose politicians and interest groups to serious critical scrutiny. Superb at generating political heat, Thai newspapers largely lack the capacity to generate light. In other words, the power and influence of the press is largely situational; considerable at crucial junctures, but much reduced at other times. Since political crises enhanced the power and influence of the press, columnists and editors had a vested interest in promoting a sense of crisis order to empower themselves. The enthusiasm of the press for generating crises is one factor underlying the frequency with which Thai cabinets and governments are replaced. Whilst the ousting of inept premiers such as Suchinda and Banharn might seem a legitimate use of press power, the ousting of Chuan in 1995 wad more questionable, and the instability and continual flux produced by almost annual changes of government is hardly in Thailand's best interests.

Ownership is an important factor in determining the political stance of individual newspapers, as wad abundantly shown during the 1991 military coup and the 1992 May events. Despite their protestations to the contrary, owners do interfere in matters such as editorial content, the tone of headlines, and decisions on whether or not to run stories considered critical of certain politicians or interest groups. There was evidence of partisan behaviour related to ownership at all the publications where I did fieldwork. Some owners seek to use their newspapers to support or to remove particular prime ministers. Even where owners do not make any explicit requests to editorial staff concerning coverage of particular issues, editors often make decisions with the known opinions, preferences and connections firmly in mind.
A good Thai subordinate does not need to be told whom his newspaper should or should not criticise: he already knows. Thus the character of newspaper ownership has a significant effect on shaping political in Thailand. The proliferation of newspapers and newspaper owners during the 1992-96 period helped contribute to a widening of political perspectives.

\section{Meeting their match: newspapers in crisis}

Having themselves contributed to the creation of numerous political crises, it was perhaps poetic justice that Thai newspapers began to experience serious difficulties from 1997 onwards. The dramatic decline in the value of the baht following its effective devaluation on 2 July 1997, precipitated a wave of calamities for the Thai economy. With the financial system awash in bad debt advertising budgets declined, newspaper sales plummeted, an layoffs of reporters became inevitable. Vanity publications an unprofitable newspapers began closing; several Phujatkan group publications were among the first to go, and Siam Post (which had been sold on twice since running the 'Dr S' story described in chapter 5) closed down at the beginning of 1998 . In retrospect, the period of my fieldwork (February 1995 to February 1996) turned out to have been the heyday of the Thai language press.

Here was an opportunity for the Thai press to adapt and to reform. The old newsgathering system of location-based reporters was extremely labour - intensive, and could scarcely be afforded in the new climate. This was an ideal time to shift from stationary reporters to roving reporters, to break down the old bureaucratic distinctions between desks, and above all to abandon the absolute distinction between news and comment. For the economic crisis was more 
than simply a problem for the press: it was an indictment of the press. Thailand's fourth estate, besotted with the self - interested opinions of phu yai, had failed to engage with the structural weaknesses in the economic and political order that allowed the financial meltdown to take place. Speaking at a seminar in Hong Kong in June 1998, Thanong Khanthong (assistant editor of The Nation) made the following defence of the Thai media's failure to notice structural economic problems which culminated in the 1997 financial meltdown:

In Thailand, Local journalists have more advantages in getting closer to government sources while foreign journalists tend to rely more on market sources We have the advantage of reading the foreign reports and also listening to the comments from the officials. We were led into believing that [officials] knew what they were doing. As it happened, they didn't know what they were doing, and the market was right...The officials are supposed to the authoritative source. They have all the figures in their hands, and we trusted them. ${ }^{31}$

The reporters, columnists and editors had failed to notice the declining efficiency of the bureaucracy, the abuses of power by ministers, and especially the colossal buildup of bad loans which had brought about Thailand's calamities. Despite market evidence to the contrary, they continued to display a naïve faith in the utterances of supposedly 'authoritative' government officials. The media mediocrity produced by a flawed system of news-gathering, coupled

${ }^{31}$ Freedom Forum, 1998 Asia Media Forum, Free Press Fair Press, Hong Kong, June 9-10, Arlington, Virginia: Freedom Forum, 1998, p. 8. with a systematic failure to analyse and to explain developments, had nicely complemented and serviced the mediocrity and incompetence so rife in the business sector, in the bureaucracy, and above all among the politicians who allegedly ran the country.

The Thai language press is one of the liveliest and most provocative in the world. Thai newspapers have contributed greatly to the openness and dynamism of Thai society. The openness of the Thai press contrasts sharply with the often turgid print media in neighbouring countries, such as Malaysia, Singapore, and (until recently) Indonesia, where censorship and self - censorship are the order of the day. Thailand has its own distinctive culture and characteristics; no one would wish to see Thai Rath turn into something like the Financial Times, or Matichon become a Thai version of the Asahi Shimbun. Nevertheless, the dubious distinction between news and comment which characterises the political coverage of the Thai language press is a major obstacle to journalistic professionalism. Overcoming such obstacles will be an important for Thai newspapers as they enter the next century. The Thai public need more than mere opinions: they deserve explanations.

\section{A three-point outline blueprint for reform of the Thai language press}

1. Replace Bangkok newspapers with national newspapers

- The concept of 'provincial news' could be abandoned.

- Local stringers could be largely replaced by full-time professional reporters, usually covering several provinces.

- Stories could be reporter - driven rather than location-driven: reporters could be trained to seek out stories where 
they occur, rather than waiting for news to happen locally.

- Investigative teams of experienced reporters could be based in Bangkok, ready to be deployed at short notice anywhere in the country when a major story breaks.

- 'Provincial' news desks could be abolished; reporters working on stories outside Bangkok could liaise directly with the relevant desk editors.

2. Quote less, explain more

- The distinction between news and comment in political stories could be dropped, in favour of writing political stories that analyse and explain developments.

- Political news stories could be shorter and ore focused, pointing out the significance of developments, and highlighting possible reasons for controversies and proposals.

- Political columns could be more factually - grounded, and less based on sheer assertion.

- Political reporters and columnists would need retraining to adopt new ways of writing.

3. Gather news differently

- Reporters in Bangkok could reduce their preoccupation with passively 'watching' (fao) centres of power, and spend more time seeking out stories.

- Reporters could distance themselves from power - holders more explicitly.

- Newspaper could send more of their best staff back out into the field, making use of their seniority and contacts to pursue important stories.

\section{References}

Boonyaketmala, Boonrak. 1982. "Thailand," in John A. Lent (ed.), Newspaper in Asia: contemporary trends and problem: 344 .

Fairclough, Gordon. "Free to air" Far Eastern Economic Review, 16 November 1995.

Girling, John L.S. 1981. Thailand: society and politics, Ithaca: Cornell University Press.

McCargo, Dancan. 1993. "The buds of May," index on Censorship: 3-8.

1999. "The international media and the domestic political coverage of the Thai press," Modern Asian Studies. 33. 3: 551-579.

McCargo, Duncan and Ramaimas Bowra. 1997. Policy advocacy and the media in Thailand, Bangkok: Institute of Public Policy Studies.

Phongpaichit, Pasuk and Chris Baker.1997. "Power in transition: Thailand in the 1990s," in Kevin Hewison (ed.), Political change in Thailand: democracy and participation: 33-5.

Pongsudhirak, Thitinan. 1997. “Thailand's media: whose watchdog?" in Kevin Hewson (ed.), Political change in Thailand: democracy and participation: 224-5.

Siriyuvasak, Ubonrat. 1994. "The development of a participatory democracy: raison d'etre for media reform in Thailand," in Southeast Asian Journal of Social Science, 22: 101-5.

Tanasomboonkit, Pajaree. 'Nangsuephim Thai Rath kap kankamnotwarasan khwam khatyaeng thang kanmuang nai hetkan pritsapa 2535', [Thai Rath Newspaper and the agenda setting of political conflict in the May crisis 1992], unpublished MA. Dissertation, Faculty of Communication Arts, Chulalongkorn University, 1995. 